\title{
The integration in educational system of children with disability - a philosophy and a legal obligation
}

Entela HOXHAJ

University of Shkodra "Luigj Gurakuqi", Albania

enhoxhaj@yahoo.com

Irma Baraku

Commissioner for Protection from Discrmination, Albania

irma_baraku@yahoo.com

\begin{abstract}
The increasing fisibility of the children with disability or special needs enhanced the debate and efforts for a new philosohy related to the treatment of disability problematics in general and, especially, to their education. The concept of diasbility has evolved to a model of integration and social inclusion, especially the social inclusion of children with disability in common schools. The law 'On the protection from discrimination' prohibits discrimination on grounds of disability, and refusal of registration in an educational institution because of this ground. Furthermore, this law provides the obligation of statal institutions to take positive measures to make possible the enhance of education of vulnerable groups, including children with disability or special needs. These provisions would lack if not accompanied with the creation of a legal framework that explicitly provide for this inclusion philosophy and create the proper mechanisms to make it applicable. It is evident the indispensability of a multi-dimensional treatment of this problematic, that requires also the collaboration of many actors. The innovative stands just in the creation of mechanisms that would make possible such an inclusion. This process requires directors of educational institutions and active and teachers, devoted on the integration of children with disability in every aspect of teaching and educational process.
\end{abstract}

Keywords: disability, inclusion, integration, reasonable appropriateness

\section{Introduction}

The treating of issues related to the education of children with disability is multidimensional. Thus, in this paper is proposed the treatment in 3 approaches:

(i) A general overview on the evolution of the concept 'disability'.

(ii) The legal framework on the rights of education for the children with disability (a comparative international approach).

(iii) The institutional mechanisms that guarantee the respect of the rights of children with disability in the field of education.

The following constitutes an attempt to highlight the indispensability of interlacing all the above aspects so that children with disabilities would be part of the qualitative education process.

\section{A general overview on the evolution of the concept 'disability'.}

The concept 'disability' has undergone an evolution that leads us from an analysis of the individual features of the child to an interlacing with the social attitude and engagement on the view and treatment of these features. The evolution or change of its meaning has been formalized through several international acts. In terms of the UN Convention on the Rights of Persons with Disabilities "persons with disabilities include those who have long-term physical, mental, intellectual or sensory impairments which in interaction with various barriers may hinder their full and effective participation in society on an equal basis with others" (UN Convention on the Rights of Persons with Disabilities, Article 1). This Convention constitutes an important document for the sanctioning of a new model of treating disability as one that imposes obligations on States parties. The Council of EU has adopted the legal framework for the implementation of this Convention (European 
Commission, 2013, p. 52). 2003 was the European Year of people with disabilities for which it was drafted an action plan (EQUINET, 2009, p. 7).

The Charter of Fundamental Rights of the European Union provides for 'disability' as one of the grounds on which discrimination is prohibited (Botim i Ministrisë së Integrimit, 2008, p. 5), but the EU legislation does not provide a definition for 'the disability'. This concept has been treated by European Court of Justice (here in after ECJ) which does not link the disability with 'the decease', but with "the limitations resulting from physical, mental and psychological impairments and impede the participation of the the individual in his professional life". This is the approach of the ECJ in the first issue addressed regarding the provision of disability by the European Council Directive 2000/78 / EC of 27 November 2000, "On the definition of a general framework for equal treatment in employment and during labor relations " (ECJ, case Chacón Navas v. Eurest Colectividades SA (2006) $\underline{\text { C-13/05). }}$.

According to EU legislation, there are two models of disability treatment: (a) the medical model that sets the problem to the sick person, and (b) the social model that draws attention to the obstacles which the society itself creates by negative attitudes, stigma and prejudice (Baraku, I., Hoti, P., 2013, pp. 205-2013). The European Court of Justice extends the protection also to individuals who are discriminated against on grounds of their association with a person with disabilities (ECJ, case S. Coleman v.Law Attridge and Law Steve (2006) C-303/06).

However, nowadays three models of understanding 'disability' are recognised: medical, social and bio-psycho-social model.

(a) The medical model sets into focus the concept of the individual with his health problems and requires that he adapt to the demands of society in which is part (Save the Children, 2013, p. 23).

(b) The social model emphasises that, despite the medical condition, the society should offer to the individuals with a disability the necessary conditions for qualitative life (Rieser, R., Mason, M., 1992, p. 15).

(c) The bio-psycho-social model is a combination of the above models. This model comes from the International Classification of Functioning, Disability and Health (here in after ICF) of WHO. ICF looks beyond the idea of a purely medical or biological conceptualization of dysfunction, taking into account the other critical aspects of disability. This alloës for the impact of the environment and other contextual factors on the functioning of an individual or a population to be considered, analyzed, and recorded (WHO homepage).

The evolution of the concept of 'disability' requires a new approach in the treatment of children with disabilities, especially their education. The following issues deal with their right to education and some aspects closely related to it.

\section{The legal framework on the rights of education for the children with disability (a comparative international approach).}

The right to education of individuals with disabilities is a challenge of the democratic societies which increasingly tend towards inclusivness processes. The equality bodies emphasize that the promotion and fulfillment of human rights needs to respect and take account of the diversity of the population and to advance inclusion and equality (EQUINET, 2011, $p$. $6)$.

The raised question is "What 'inclusion' means?".

To be inclusive requires that we strive to identify and remove all barriers to learning for all the children. This means that we must attend to increasing participation not just for disabled students but for all those experiencing disadvantage (Ballard, K., 1999, p. 1).

Albania is the $127^{\text {th }}$ country that ratified, with the law no. 108 / 2012, the UN Convention on the Rights of Persons with Disabilities that provides special protection for the children with disabilities, to ensure that these children enjoy all rights and fundamental freedoms (UN Convention on the Rights of Persons with Disabilities, Article 7). On the other side its Article 24 pays attention to the obligation of States parties to guarantee the right of persons with disabilities to education, by not allowing them to be excluded from general education, free education and the primary compulsory primary due to disability.

The "qualitative education" as a model which should support the process of learning, is the focus of the Dakar Framework for Action adopted by the World Education Forum in Senegal in 2000. This concept should be also aimed for the children with disabilities because it exceeds the concept of 'intergrated education' which is based on the medical model of disability 
and reinforces the concept of 'inclusive education', which aims to the access, the participation and the achievement of results within the process (Save the Children, 2013, pp. 21-23).

Given that the first criterion for a comprehensive education is access, it would be of interest to give an overview of the current situation of school attendance of children with disabilities. According to INSTAT data (Instat is the Albanian Institute of Statistics), the number of children with disabilities registered in the compulsory education is 2.400 , including the disabled students of the special schools. This number constitutes only $5 \%$ of the total number of children registered in the cumpolsory education (INSTAT homepage). Meanwhile, according to a study realized by Save the Children, the total number of children with disabilities in kindergardens and primary schools for the scholastic year 2011-2012 results as following:

- 511 children in kindergardens that is $0,49 \%$ of the total number (103.492) of children frequenting common kindergardens, - 3.167 children in the primary schools that is $0,64 \%$ of the total number (472.892) of children frequenting common schools. Thus, the total number of children with disabilities in common education is 3.678 that constitutes $0,63 \%$ of the total number of 576.383 children frequenting common education.

In the legal perspective, the first step towards guaranteeing the right to education of children with disabilities is its provision in the fundamental law of the state. It was also highlighted by Goldsworthy, according to which "the contemporary constitutional doctrine is based on a democratic liberal constitutional model based on four columns; one of these columns is the guarantee of individual rights" (Anastasi, A., 2009, p. 78). In this regard, the Albanian Constitution contains some provisions that guarantee this right. Prof. Anastasi highlighted that fundamental rights (including the right to education) are formally guaranteed by the Constitution through several facts:

(i) The provision of a set of principles such as those of direct democracy, the separation of powers, equality and nondiscrimination.

(ii) Setting margins on the extent to which the fundamental rights can be limited.

(iii) The provision of constitutional mechanisms for the protection of fundamental rights - Ombudsman, and the right to protect these rights by court way (Anastasi, A., 2009, pp. 80-81).

The adoption of legislation in conformity with international acts has been, and yet remains, an important obligation for Albania. The Constitutional Court plays an indisputable role in the protection of these rights, through addressing the constitutionality of laws and also their incompatibility with international acts ratified by the Republic of Albania (Albanian Constitutional Court, Decision no. 48 / 2013). In this respect it "bases its opinions not only on the text of the convention, but also the interpretation that the European Court of Human Rights has made on its provisions" (Anastasi, A., 2009, p. 84)

The law "On the pre-university education in the Republic of Albania", adopted in 2012 guarantees and promoted the inclusion of more children with disabilities in common schools. It has brought several innovations:

- It gives an understanding of disability according to international standards.

- It provides the principle of non-discrimination of children with disabilities in the exercise of the right to education.

- It enables the involvement of many stakeholders in education issues, especially the children and their parents, but also of psychologists and social workers.

During 2013, the Normative Dispositions "On Pre-university Education System" were approved; they provided detailed procedures and rules for the education of children with disabilities.

The law "On the Protection from Discrimination" prohibits the discrimination based on disability, and the refusal to accept in an educational institution because of it. The provision of 'discrimination because of association' as one of the forms of discrimination is a guarantee in the support of the parents of disabled children (KMD, Decision no. 54 / 2014). On the other hand, this law provides the obligation of state institutions to take positive measures to enable the promotion of education of vulnerable groups, including the children with disabilities and special needs.

In certain cases, certain individuals or groups have the same opportunities to realize their rights and "governments, employers and service providers must ensure that they take steps to adjust their rules and practices to take such differences into consideration - that is, they must do something to adjust current policies and measures... By taking special measures, governments are able to ensure 'substantive equality', that is, equal enjoyment of opportunities to access benefits available in society, rather than mere "formal equality" (FRA, 2010, p. 35). The Albanian Law On protection from Discrimination 
charges the Council of Ministers and the Minister of Education with the responsibility to take measures for the respect and ensuring of the right to education for persons with disabilities in the appropriate ways.

The 'reasonable adjustment' is another necessary condition for the inclusion of children with disabilities in the common base education. 'The denial of reasonable adjustment' is a form of discrimination provided by the Law On protection from Discrimination. However, this law does not provide a definition of this term. Even in light of European legislation, there is an absence of explicit provisions requiring a reasonable accommodation (Commissioner for Human Rights, 2011, p. 7). Although this term in everyday language relates primarily to the costs of this process, the experts in the field think that it could relate to the quality of the accommodation itself and mean that the accommodation must be effective (European Communities, 2009, p. 26). The reasonable adjustment relates primarily to the elimination of barriers to the accessibility to educational institutions. The lack of access to buildings and public spaces yet is one of the main barriers to achieving equality in the education of children with disabilities. However, this would be a very narrow interpretation of this concept; it should include the preparation of learning materials in a suitable format for the type of disability.

\section{The institutional mechanisms that guarantee the respect of the rights of children with disability in the field of education.}

The indispensability for the multi-dimensional treatment of the related problematic is evident. Thus, it is required the collaboration of several stakeholders. The innovation especially stands in setting the mechanisms that would make effective the inclusiveness. The following treats the mechanisms set up by:

(a) the educational institutions,

(b) the Commissioner for Protection from Discrimination,

(c) the judicial way to protect the right to education of children with disabilities.

(a) The educational institutions. The local educational unit should establish a commission, consisting of doctors, psychologists, teachers and specialists for children with disabilities. This commission provides the relevant recommendations for the child's attendance in a common educational institution or a specialized one after examining the request of a parent or a director of an educational institution. It recommends attendance in a specialized school only when it deems that the pursuit of a common school would not appropriately develop the child with disabilities. However, the decision is up to the parents to decide whether their child with disabilities will attend a specialized educational institution or a common one.

To integrate children with disabilities into every aspect of teaching and educational process, it requires active and dedicated directors of educational institutions and teachers. They are legally charged to develop personalized programs for students with disabilities, through the special commission refered above. The development of these programs is done in collaboration with the parents and the children. Ensuring the inclusiveness seeks to give support provided by law for the teacher who has in his class children with disabilities or special needs. This support can be accorded by giving available additional teachers, creating a class with a smaller number of students, etc.

It is equally important that the directors of educational institutions consistently take measures to raise the awareness of all stakeholders (teachers, parents, and students) and to treat any discriminatory phenomenon within the school environment. According to the Law On protection from Discrimination, they should address any complaint about discrimination within these facilitie. It also determines the deadlines for their handling of appropriate disciplinary measures to avoid discriminatory situations. In this perspective, the fight against prejudice against children with disabilities takes appropriate importance by promoting their integration within the premises of the educational institution.

(b) The Commissioner for Protection from Discrimination is an independent institution created to guarantee everyone's rights against discriminatory behaviours and discriminatory stimulating behaviours, on grounds of an open list among which disability. The Commissioner has the power to assist victims of discriminating behaviour through reviewing complaints, administrative investigations, through the drafting of reports and even recommendations. This institution is similar to 
equality institutions in EU countries. It is an institution built on the Paris Principles that are applied as a standard for equality institutions. It is also created in conformity with

article 13 of the Council Directive 2000/43/EC of 29 June 2000 "On the principle of equal treatment between persons irrespective of racial or ethnic origin" (EQUINET, 2010, pp. 9-10).

Although the improvement of the legal framework, the Commissioner has noticed that there are times when children with disabilities were denied admission to common schools. During his practice the Commissioner found the discrimination of children with disabilities due to the failure of the structures responsible for evaluating the student's individual needs through Multidisciplinary Commissions, pursuant to the applicable provisions governing the education of children with disabilities (KMD, Decision no. 92 / 2013). The Commissioner ascdertained that these legal provisions on education were too little known or overlooked by the directors of educational institutions and by the Regional Education Directorates and Offices, which have a major role in their implementation. Thus, disabled child is denied the right to be included in the common basic education or even when he enters, yet does not take the education in accordance with the legal requirements and in qualitative way affecting the future expected performance. Any deviation from the implementation of these obligations places children with disabilities in a discriminatory situation (KMD, 2013, p. 11).

\section{(c) The judicial way to protect the right to education of children with disabilities.}

The public administration must respect the Constitution, the legislation in force and fundamental human rights during its activity. However, reality brings cases of continuous violations by the executive institutions, and not only them. Lawyers and researchers highlight the necessity of creating mechanisms that would ensure the respect of fundamental rights by emphasizing the obligation of public administration to meet its extensive objectives that are constitutional wide ones (Dobjani, E., Puto, E., Dobjani, E., \& Toska E., 2013, p. 265). Prof. Anastasi on this regard raises the question: Can only negative rights be protected in court or even socio-economic rights can enjoy this opportunity? According Anastasi, in the case of the right to education "it can not be denied the ability of the courts to force the state to give equal opportunity in order to be educated according to the skills of everyone" (Anastasi A., 2009, p. 88). Upon studying and analysing, in the following are listed some recommendations on educational institutions in Albania regarding the integration in the educational system of children with disability:

\section{Recommendations}

- Managerial staff of educational institutions and teachers should be trained continuously for a clear understanding of the concepts 'inclusive and qualitative education' as well as a treatment model for disability.

- To ensure effective implementation of new legislation adopted in the field of education in Albania, there should be taken measures aiming at the inclusion of children with special needs or disabilities in common schools, by offering a qualified and personalized treatment.

- To eliminate barriers to buildings, transportation, teaching methods and communication, the responsible state institutions must take measures to ensure that children with disabilities enjoy on equal basis with others and without discrimination the right to education.

- Within educational programs it should be included the concept of discrimination and its forms of appearance in order to raise awareness, respect for diversity and reduce prejudice for children with disabilities.

- Statistical data on the inclusion of children with disabilities in the educational process should be updated especially highlighting their numbers in common schools.

\section{Literature}

[1] (INSTAT homepage) www.instat.gov.al

[2] Albanian Constitutional Court, Decision no. 48 / 2013 (no. 48, date 15.11.2013), (www.gjk.gov.al)

[3] Anastasi, A., 2009, E drejta kushtetuese e krahasuar (Raste nga praktika kushtetuese dhe leksione për studentët e drejtësisë), Tiranë.

[4] Ballard, K., 1999, Inclusive Education: International Voices on Disability and Justice, Philadelphia. 
[5] Baraku, I., Hoti, P., 2013, The concept of discrimination and other concepts related to it in the albanian legislation - comparative overview with the EU directives in the anti-discrimination field, in Proceedings book of '4th International Conference on European Studies - Social, Economic and Political Transition of the Balkan', organizad by EPOKA University, Tiranë, 8-9 November 2013.

[6] Botim i Ministrisë së Integrimit, 2008, Versioni i konsoliduar i Traktateve të Bashkimit Europian dhe Karta e të Drejtave Themelore e Bashkimit Europian, Tiranë.

[7] Commissioner for Human Rights, 2011, Opinion of the Commissioner for Human Rights on National Structures for Promoting Equality, Strasbourg.

[8] Dakar Framework for Action, 2000, World Education Forum, Senegal.

[9] Dobjani, E., Puto, E., Dobjani, E., \& Toska E., 2013, E drejta administrative - Kontrolli mbi Administratën Publike, Tiranë.

[10] ECJ, case Chacón Navas v. Eurest Colectividades SA (2006) $\underline{\text { C-13/05. }}$

[11] ECJ, case S. Coleman v.Law Attridge and Law Steve (2006) C-303/06).

[12] EQUINET (European Network of Equality Bodies), 2009, Towards a new European Union Disability Action Plan, Belgium.

[13] EQUINET (European Network of Equality Bodies), 2010, Influencing the law through legal proceedings - The powers and practices of equality bodies, Belgium.

[14] EQUINET (European Network of Equality Bodies), 2011, Equality bodies and National Human Rights Institutions-Making the Link to Maximise Impact, Belgium.

[15] European Commission, 2013, 2012 Report on the Application of the EU Charter of Fundamental Rights, Belgium, European Commission, Directorate - General for Justice.

[16] European Communities, 2009, Disability and non-discrimination law in the European Union, Luxembourg.

[17] FRA (European Union Agency for Fundamental Rights), 2010, Handbook on European non-discrimination law, Luxembourg, European Union Agency for Fundamental Rights, Council of Europe

[18] KMD, 2013, Annual Report 2013 of the Commissioner for Protection from Discrimination, Tiranë.

[19] KMD, Decision no. 54 / 2014 (The Albanian Commissioner for Protection from Discrimination www.kmd.al)

[20] KMD, Decision no. 92 / 2013 (The Albanian Commissioner for Protection from Discrimination www.kmd.al)

[21] Principles relating to the Status of National Institutions, Adopted by General Assembbly resolution 48/134 of 20 December 1993 (The Paris Principles).

[22] Rieser, R., Mason, M., 1992, Disability equality in education, London.

[23] Save the Children, 2013, Analitical Study 'Arsimi gjithëpërfshirës në Shqipëri', Tiranë, Save the Children.

[24] UN Convention on the Rights of Persons with Disabilities (http://www.un.org/disabilities/convention/conventionfull.shtml).

[25] WHO homepage (http://www.who.int/classifications/icf/icf more/en/). 